\title{
Classification of Crude Oils and its Fractions on the Basis of Paraffinic, Naphthenic and Aromatics
}

\author{
Wedad H. Al-Dahhan* and Shaymaa MA Mahmood \\ Department of Chemistry, College of Science, Al-Nahrain University, Baghdad-Iraq. \\ *Corresponding author: dahan6262@gmail.com
}

\begin{abstract}
The ratios of crude oils hydrocarbons vary according to its origin. Two types of crude oil $(A \& B)$ were selected from Dura refinery which was extracted from Basra oil fields. These samples were tested according to physical properties: density, Specific gravity, API gravity, Pour Point, Kw factor and Correlation Index. Results show that crude oil (A) heavier than (B) due to higher density; pour point and lowers (API). Crude oil (A) shows it has more aromatic compounds than the crude oil (B) according to its higher (Kw) and lower (CI) values or (B) contain more paraffinic compounds than (A) for the same reasons. Atmospheric distillation process was done according to ASTM 2892 method for the two selected crude oils. Fractions obtains were tested according to physical properties: density, Aniline Point, API gravity, Kw factor and Correlation Index. The nature of the ingredients for petroleum fractions derived from distillation of the crude oil samples can be classified on the basis of the Paraffinic, naphthenic or aromatic content, depending on the results obtained from distillation which confirm the findings stated above for crude oil. Fourier Transform Infrared Analysis was carried out for crude oils atmospheric fractions to identify the components in terms of being paraffinic, naphthenic or aromatics. Results refers to the same ingredients for crude oil B for the paraffinic and naphthenic components as in crude oil A but the main difference here is the disappearance of the bands for aromatics $\mathrm{C}-\mathrm{H}$ stretching occur above $3000 \mathrm{~cm}^{-1}$ for crude oil B which refers that this crude has less aromatic compounds than crude oil A. These results have been confirmed through ultraviolet tests. [DOI: 10.22401/ANJS.22.3.05]
\end{abstract}

Keywords: Crude oil, Distillation, FT-IR, Ultraviolet.

\section{1-Introduction}

Crude oil mainly contains hydrocarbons with a small proportion of other chemical compounds that can contain nitrogen, oxygen or sulphur and can contain elements such as iron, nickel, copper and palladium [1]. These components directly affect refining processes as well as the methods of analysis adopted [2].

The ratios of crude oils hydrocarbons vary according to its origin. The distribution of hydrocarbons to different types of crude oil depends on the petroleum reservoirs. The chemical and physical properties of this permeability will vary according to the different origins [3].

The most important and most common hydrocarbons in crude oil are the straight and branched alkanes (called paraffins), cycloalkanes (called naphthenes), aromatic hydrocarbons and the most complex chemical substances, such as the asphaltic ingredients, its molecular weight is 800-2500[4]. Hydrocarbons have a range of (15-60\%) for paraffins, (30-60\%) for naphthenes, (3-30\%) for aromatics and the remainder is asphaltics [5].

Crude oil with low carbon, high hydrogen and high API (American Petroleum Institute) is rich in paraffins and produces large quantities of gasoline and light petroleum products, but oil with a large carbon, low hydrogen and a low API rich in animates, the first oil is called light oil and the second is called heavy oil [6]. Crude oil can be classified on the basis of the nature of its main hydrocarbons components as paraffinic, naphthenic or aromatic. The ratios of these ingredients vary in oil fractions resulting from crude oil distillation [7].

This work aims to identify two types of crude oil and its fractions on the basis of Paraffinic, Naphthenic and Aromatics using physical properties and spectrophotometric analysis.

\section{Experimental}

2.1. API (American Petroleum Institute) API gravity used to specify the specific gravity 
(SG) of the crude oil as API $=(141.5 / \mathrm{SG})-$ 131.5. SG is the specific gravity which is defined as the ratio of the density of the crude oil to the density of water at $15.6{ }^{\circ} \mathrm{C}\left(60{ }^{\circ} \mathrm{F}\right)$ for both. The API gravity classification illustrated in Table 1[8].

Table (1)

The API gravity classification.

\begin{tabular}{||c||c|}
\hline API gravity & Description \\
\hline \hline less than 10 & very heavy crudes \\
\hline between 10 and 30 & heavy crudes \\
\hline \hline between 30 and 40 & medium crudes \\
\hline \hline above 40 & light crudes \\
\hline \hline
\end{tabular}

Density and specific gravity at a temperature of $20^{\circ} \mathrm{C}$ was determined according to ASTM 1217.

\subsection{Crude oil classification by characterization factor}

Since then, oil factories have been willing to draw up classifications based on practical mathematical bases for classifying the identity of hydrocarbons in crude oil, Watson "characterization factor" $(\mathrm{Kw})$ is one of the oldest indicators used to categorize the identity of crude oil[9]. Equation (1) illustrates how to calculate $(\mathrm{Kw})$ and correlation index $(\mathrm{CI})$ as shown in equation (2) [10].

$\mathrm{Kw}=(\mathrm{TB})^{1 / 3} / \mathrm{G}$

$\mathrm{CI}=87552 / \mathrm{TB}+473.7 \mathrm{G}-456.8$

(TB) is the average boiling point in degrees Rankine $\left({ }^{\circ} \mathrm{F}+460\right)$

(G) is the specific gravity $60^{\circ} / 60^{\circ} \mathrm{F}$.

Highly paraffin oils have $\mathrm{K}$ in the range 12.5 to 13.0 and cyclic (naphthene) oils have $\mathrm{K}$ in the range 10.5 to 12.5 . The $\mathrm{CI}$ scale is based upon straight-chain paraffins having a $\mathrm{CI}$ value of (0) and benzene having a $\mathrm{CI}$ value of (100). The lower the CI value, the greater the concentration of paraffin hydrocarbons in the fraction, and higher the CI value, the greater the concentration of naphthenes and aromatics [11].

\subsection{Aniline point}

Aniline point can be defined as the lowest temperature possible to blend equal volumes from liquid petroleum fraction with aniline.
The degree of aniline is important in the knowledge of the properties of the petroleum fractions which increases with molecular weight and carbon number increases. For equal number of carbon, aniline point increases for the largest proportion of the paraffin and decreases for aromatics present in petroleum fractions [10]. Therefore, the aniline point is an indicator that is highly related to the hydrocarbon types in petroleum fractions [12].The aniline point has been measured according to ASTM-D 611[7].

\subsection{Crude oil distillation}

Distillation under normal atmospheric pressure separates the ingredients of crude oil into oil derivatives with slightly different boiling points [13]. The distillation of crude oil or petroleum includes two types, first distillation under normal atmospheric pressure and the other under vacuum. In the first, it produces oil fractions called straight run products, the most important of which are the gasoline, kerosene and gas oil while vacuum distillation products include mainly vacuum gas oil (VGO) [14]. From distillation operations under normal atmospheric pressure, it is possible to obtain important data on the boiling points of the oil products against the volumes produced for those derivatives, through which the distillation curve can be drawn, the quantities of the gasoline, kerosene, gas oil and heavy residues within this stage [15]. Atmospheric distillation was done using the ASTM D 2892 method and at temperatures not exceeding $350^{\circ} \mathrm{C}$ to avoid thermal cracking within this stage [16]. Two samples of crude (A \& B) recovered from Dura oil refinery, distillation has been carried out in distillation apparatus, according to ASTM-D 2892.The standard limits for crude oil atmospheric distillation fractions are: $(32.2-104.4)^{\circ} \mathrm{C}$ for gasoline, (104.4-157) ${ }^{\circ} \mathrm{C}$ for naphtha, (157$232)^{\circ} \mathrm{C}$ for kerosene, $(232-426)^{\circ} \mathrm{C}$ for gas oil and $\left(>426{ }^{\circ} \mathrm{C}\right)$ for residuum (including asphalt) [17].

\section{Results and Discussion}

\subsection{Properties of the selected crude oils \\ 3.1.1. Physical properties}

It is important to get the main specifications of the crude oil samples under 
study before going into the specifications of the crude oil fractions of the two selected crude oils. Table (2) shows that crude oil (A) heavier than (B) due to higher density, pour point and lowers (API) (see section 2.1). Crude oil (A) shows it has more aromatic compounds than the crude oil (B) according to its higher $(\mathrm{Kw})$ and lower $(\mathrm{CI})$ values or $(\mathrm{B})$ contain more paraffinic compounds than (A) for the same reasons (see section 2.2).

Table (2)

Physical properties of the crude oils $(A \& B)$.

\begin{tabular}{|c|c|c|c|c|c|c|c|}
\hline $\begin{array}{l}\text { Crude } \\
\text { Type }\end{array}$ & $\begin{array}{c}\text { Density } \\
\mathrm{g} / \mathrm{cm}^{3} \\
\left(20^{\circ} \mathrm{C}\right) \\
\end{array}$ & $\begin{array}{c}\text { Density } \mathrm{g} / \mathrm{cm}^{3} \\
\left(15.6^{\circ} \mathrm{C}\right)\end{array}$ & $\begin{array}{c}\text { Specific } \\
\text { gravity } \\
\left(15.6^{\circ} \mathrm{C}\right) \\
\end{array}$ & $\begin{array}{c}\text { API } \\
\text { gravity }\end{array}$ & $\begin{array}{l}\text { Pour Point } \\
\left({ }^{\circ} \mathrm{C}\right)\end{array}$ & $\begin{array}{c}\text { Kw Factor } \\
\left({ }^{\circ} \mathbf{R}\right)\end{array}$ & $\begin{array}{c}\text { Correlation } \\
\operatorname{Index}(\mathrm{CI})\end{array}$ \\
\hline A & 0.84 & 0.85 & 0.85 & 34.97 & -18 & 11.64 & 5.44 \\
\hline B & 0.76 & 0.78 & 0.78 & 49.91 & -25 & 11.92 & $<0$ \\
\hline
\end{tabular}

\subsubsection{Atmospheric Distillation Results}

Atmospheric distillation process was done according to ASTM 2892 method. Results from distillation for crude oil (A) and (B) illustrated in Table (3 and 4) respectively and Fig.(1).

Table (3)

Crude oil (A) atmospheric distillation results.

\begin{tabular}{|c|c|c|c|c|c|c|c|c|c|c|}
\hline $\begin{array}{l}\text { Cumulative } \\
\text { Volume \% }\end{array}$ & $\begin{array}{c}\text { Boiling } \\
\text { Point } \\
{ }^{\circ} \mathrm{C}\end{array}$ & $\begin{array}{c}\text { Density } \\
\text { g/cm }{ }^{3} \\
\left(20^{\circ} \mathrm{C}\right)\end{array}$ & $\begin{array}{c}\text { Density } \\
\text { g/cm } \mathbf{c m}^{3} \\
\left(15.6^{\circ} \mathrm{C}\right)\end{array}$ & $\begin{array}{c}\text { Specific } \\
\text { gravity } \\
\left(15.6^{\circ} \mathrm{C}\right)\end{array}$ & $\begin{array}{c}\text { API } \\
\text { gravity }\end{array}$ & $\begin{array}{l}\text { Aniline } \\
\text { point } \\
\left({ }^{\circ} \mathrm{C}\right)\end{array}$ & $\begin{array}{c}\text { Pour } \\
\text { Point } \\
\left({ }^{\circ} \mathrm{C}\right)\end{array}$ & $\begin{array}{c}\text { Kw } \\
\text { Factor } \\
\left({ }^{\circ} \mathbf{R}\right)\end{array}$ & $\begin{array}{l}\text { Correlati } \\
\text { on Index } \\
\text { (CI) }\end{array}$ & : \\
\hline First drop & 107 & - & - & - & - & & - & - & - & \multirow{2}{*}{ 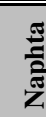 } \\
\hline 5 & 151 & 0.71 & 0.73 & 0.73 & 62.33 & 58.9 & -30.6 & 13.56 & $<0$ & \\
\hline 10 & 187 & 0.75 & 0.77 & 0.77 & 52.26 & 56.0 & -28.1 & 12.85 & $<0$ & \multirow{3}{*}{ 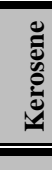 } \\
\hline 15 & 203 & 0.79 & 0.80 & 0.80 & 45.37 & 53.1 & -25.0 & 12.37 & $<0$ & \\
\hline 20 & 238 & 0.82 & 0.84 & 0.84 & 36.95 & 50.0 & -21.1 & 11.78 & 1.07 & \\
\hline 25 & 281 & 0.86 & 0.89 & 0.89 & 27.48 & 48.2 & -15.3 & 11.12 & 22.95 & \multirow{6}{*}{$\bar{\sigma}$} \\
\hline 30 & 295 & 0.89 & 0.90 & 0.90 & 25.72 & 40.9 & -11.3 & 11.00 & 27.33 & \\
\hline 35 & 307 & 0.90 & 0.92 & 0.92 & 22.30 & 40.0 & -9.6 & 10.76 & 36.08 & \\
\hline 40 & 321 & 0.90 & 0.92 & 0.92 & 22.30 & 38.7 & -6.7 & 10.76 & 36.08 & \\
\hline 45 & 332 & 0.93 & 0.95 & 0.95 & 17.44 & 38.0 & -4.4 & 10.42 & 49.21 & \\
\hline 50 & 346 & 0.93 & 0.95 & 0.95 & 17.44 & 35.3 & -3.2 & 10.42 & 49.21 & \\
\hline
\end{tabular}


Table (4)

Crude oil (B) atmospheric distillation results.

\begin{tabular}{|c|c|c|c|c|c|c|c|c|c|c|}
\hline $\begin{array}{c}\text { Cumulative } \\
\text { Volume } \\
\%\end{array}$ & $\begin{array}{c}\text { Boiling } \\
\text { Point } \\
\left({ }^{\circ} \mathrm{C}\right)\end{array}$ & $\begin{array}{c}\text { Density } \\
\text { g/cm } \mathbf{c m}^{3} \\
\left(20^{\circ} \mathrm{C}\right)\end{array}$ & $\begin{array}{c}\text { Density } \\
\text { g/cm3 } \\
\left(15.6^{\circ} \mathrm{C}\right)\end{array}$ & $\begin{array}{c}\text { Specific } \\
\text { gravity } \\
\left(15.6^{\circ} \mathrm{C}\right)\end{array}$ & $\begin{array}{c}\text { API } \\
\text { Gravity }\end{array}$ & $\begin{array}{l}\text { Aniline } \\
\text { point } \\
\left({ }^{\circ} \mathrm{C}\right)\end{array}$ & $\begin{array}{l}\text { Pour } \\
\text { Point } \\
\left({ }^{\circ} \mathrm{C}\right)\end{array}$ & $\begin{array}{c}\text { Kw } \\
\text { Factor } \\
\left({ }^{\circ} \mathbf{R}\right)\end{array}$ & $\begin{array}{l}\text { Correlation } \\
\text { Index (CI) }\end{array}$ & 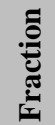 \\
\hline First drop & 67 & - & - & - & - & - & - & - & - & \multirow{3}{*}{ 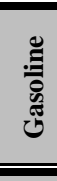 } \\
\hline 5 & 93 & 0.63 & 0.65 & 0.65 & 86.19 & 69.0 & -50.0 & 14.30 & $<0$ & \\
\hline 10 & 119 & 0.65 & 0.67 & 0.67 & 79.69 & 65.2 & -47.9 & 13.88 & $<0$ & \\
\hline 15 & 132 & 0.69 & 0.70 & 0.70 & 70.64 & 61.6 & -45.6 & 13.28 & $<0$ & \multirow{3}{*}{$\begin{array}{l}\frac{\pi}{\tilde{E}} \\
\frac{\mathrm{E}}{\mathrm{E}} \\
\frac{\pi}{\mathrm{Z}}\end{array}$} \\
\hline 20 & 143 & 0.71 & 0.72 & 0.72 & 65.02 & 58.3 & -41.2 & 12.91 & $<0$ & \\
\hline 25 & 168 & 0.73 & 0.75 & 0.75 & 57.16 & 58.0 & -35.0 & 12.40 & $<0$ & \\
\hline 30 & 180 & 0.77 & 0.80 & 0.80 & 45.37 & 53.2 & -30.6 & 111.62 & 1.00 & \multirow{4}{*}{ 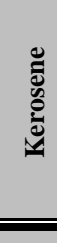 } \\
\hline 35 & 210 & 0.81 & 0.81 & 0.81 & 43.19 & 44.3 & -27.3 & 11.48 & 5.53 & \\
\hline 40 & 232 & 0.81 & 0.82 & 0.82 & 41.06 & 41.6 & -26.3 & 11.34 & 9.91 & \\
\hline 45 & 241 & 0.83 & 0.85 & 0.85 & 34.97 & 39.1 & -19.8 & 10.94 & 23.04 & \\
\hline 50 & 265 & 0.85 & $\begin{array}{l}0.87 \\
\end{array}$ & $\begin{array}{l}0.87 \\
\end{array}$ & 31.14 & 36.2 & -11.1 & 10.68 & 31.79 & \\
\hline
\end{tabular}

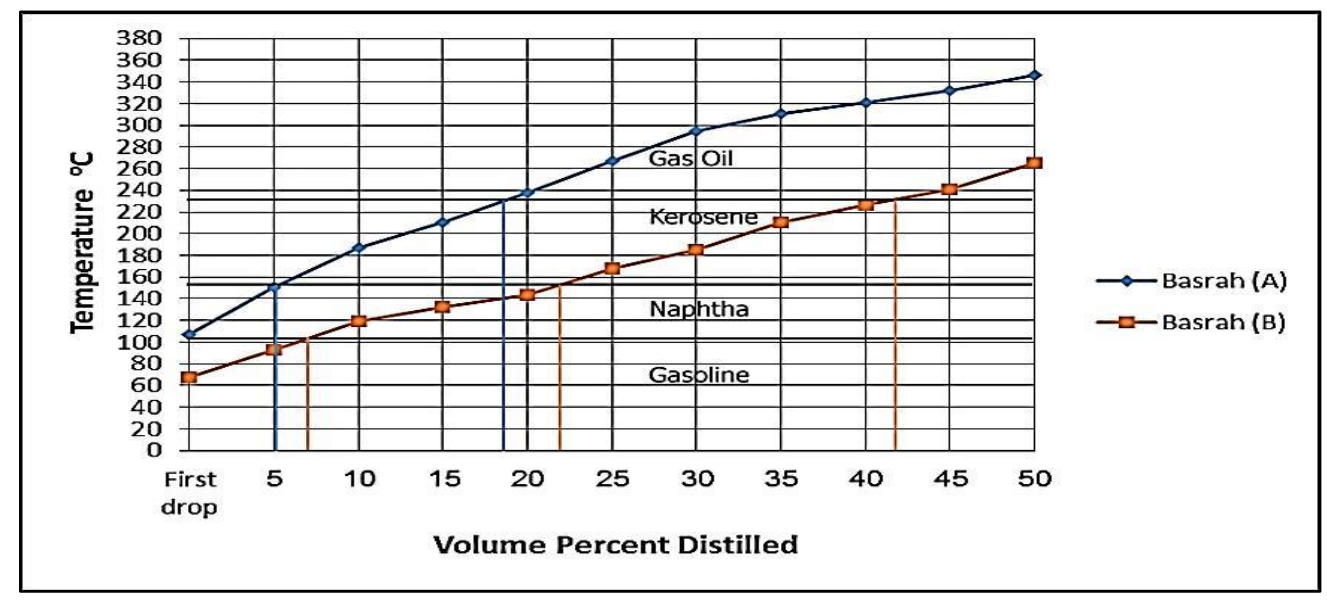

Fig.(1): Distillation curve for crude oil samples $(A \& B)$.

Table (5)

Straight run crude oil fractions from crude oils distillation curve.

\begin{tabular}{|c||c||c|c|c|}
\hline \hline \multirow{2}{|c||}{ Fractions } & Gasoline & Naphtha & Kerosene & Gas oil \\
\cline { 2 - 5 } Crude Oil & \multicolumn{3}{|c|}{ Volume Percent Distilled } \\
\hline \hline A & - & 5 & 13 & 32 \\
\hline B & 7 & 16 & 20 & 7 \\
\hline
\end{tabular}

3.1.3. Physical properties analysis along atmospheric distillation products

The nature of the ingredients for petroleum fractions derived from distillation of the crude oil samples can be classified on the basis of the Paraffinic, naphthenic or aromatic content, depending on the results obtained from distillation (see section 2.4) and some of the physical properties listed in the section 2.1, 2 and 3. These classifications can be summarized in Table (6) for fractions derived from crude oil (A) and the Table (7) for fractions derived from crude oil (B). 
Table (6)

Physical properties analysis along crude oil type (A) atmospheric distillation products.

\begin{tabular}{|c|c|c|c|c|}
\hline $\begin{array}{l}\text { Physical } \\
\text { Properties } \\
\text { Fraction }\end{array}$ & API gravity & Aniline Point & Kw Factor $\left({ }^{\circ} \mathbf{R}\right)$ & $\begin{array}{c}\text { Correlation } \\
\text { Index(CI) }\end{array}$ \\
\hline Gasoline & - & - & - & - \\
\hline Naphtha & $\begin{array}{l}\text { low Specific } \\
\text { gravity, high } \\
\text { API, light } \\
\text { fraction }\end{array}$ & $\begin{array}{l}\text { High temperature } \\
\text { low aromatic, high } \\
\text { paraffinic } \\
\text { compounds }\end{array}$ & $\begin{array}{l}\text { High value }(13.56) \\
\text { so, the fraction } \\
\text { consider as paraffinic }\end{array}$ & $\begin{array}{c}\text { The value is zero, the } \\
\text { fraction consider as } \\
\text { paraffinic }\end{array}$ \\
\hline Kerosene & $\begin{array}{l}\text { low Specific } \\
\text { gravity, high } \\
\text { API, lighter than } \\
\text { gas oil, heavier } \\
\text { than naphtha }\end{array}$ & $\begin{array}{l}\text { High temperature } \\
(52.26-36.95)^{\circ} \mathrm{C} \\
\text { It has highly } \\
\text { percent of } \\
\text { paraffinic } \\
\text { compounds } \\
\end{array}$ & $\begin{array}{l}\text { High value(12.73- } \\
\text { 11.78) so, the fraction } \\
\text { consider as paraffinic }\end{array}$ & $\begin{array}{l}\text { The value ranged } \\
\text { between zero and } \\
\text { (1.07), the fraction } \\
\text { consider as paraffinic }\end{array}$ \\
\hline Gas Oil & $\begin{array}{c}\text { Heaviest } \\
\text { atmospheric } \\
\text { distillation } \\
\text { fraction, has low } \\
\text { API }\end{array}$ & $\begin{array}{l}\text { The temperature } \\
\text { decreases as } \\
\text { aromatic } \% \\
\text { increases. so, this } \\
\text { fraction consider as } \\
\text { it is aromatic rather } \\
\text { than it is paraffinic }\end{array}$ & $\begin{array}{l}\text { The value decreases } \\
\text { between (11.12- } \\
\text { 10.42). so, the } \\
\text { fraction consider as } \\
\text { naphthenic to } \\
\text { aromatic rather than } \\
\text { paraffinic }\end{array}$ & $\begin{array}{l}\text { The value increases } \\
\text { from (22.95) to } \\
(49.21) \text {. so, } \\
\text { paraffinic compounds } \\
\text { decreases in this } \\
\text { fraction with } \\
\text { increasing naphthens } \\
\text { and aromatics }\end{array}$ \\
\hline
\end{tabular}

\section{Table (7)}

Physical properties analysis along crude oil type (B) atmospheric distillation products.

\begin{tabular}{|c|c|c|c|c|}
\hline $\begin{array}{l}\text { Physical } \\
\text { Properties } \\
\text { Fraction }\end{array}$ & API gravity & Aniline Point & Kw Factor $\left({ }^{\circ} \mathbf{R}\right)$ & $\begin{array}{c}\text { Correlation } \\
\text { Index(CI) }\end{array}$ \\
\hline Gasoline & $\begin{array}{l}\text { lowest Specific } \\
\text { gravity, highest } \\
\text { API, lighter } \\
\text { fraction }\end{array}$ & $\begin{array}{c}\text { Highest temperature, } \\
\text { very low aromatics, } \\
\text { highest paraffinic } \\
\text { compounds }\end{array}$ & $\begin{array}{l}\text { Highest value (14.30) } \\
\text { so, the fraction } \\
\text { consider as paraffinic }\end{array}$ & $\begin{array}{c}\text { The value is zero ,the } \\
\text { fraction consider as } \\
\text { paraffinic }\end{array}$ \\
\hline Naphtha & $\begin{array}{l}\text { low Specific } \\
\text { gravity, high } \\
\text { API, light } \\
\text { fraction }\end{array}$ & $\begin{array}{l}\text { High temperature low } \\
\text { aromatics, high } \\
\text { paraffinic compounds }\end{array}$ & $\begin{array}{l}\text { High value (13.56) } \\
\text { so, the fraction } \\
\text { consider as paraffinic }\end{array}$ & $\begin{array}{c}\text { The value is zero ,the } \\
\text { fraction consider as } \\
\text { paraffinic }\end{array}$ \\
\hline Kerosene & $\begin{array}{l}\text { Specific gravity, } \\
\text { API shows it is } \\
\text { liter than gas oil, } \\
\text { heavier than } \\
\text { naphtha }\end{array}$ & $\begin{array}{l}\text { Temperature range } \\
(53.2-39.11)^{\circ} \mathrm{C} \text { shows } \\
\text { decrease in paraffinic } \\
\text { compounds with } \\
\text { increasing of } \\
\text { naphthenic and } \\
\text { aromatic compounds }\end{array}$ & $\begin{array}{l}\text { High value(13.28- } \\
12.91) \text { so, the } \\
\text { fraction consider as } \\
\text { paraffinic }\end{array}$ & $\begin{array}{c}\text { The value ranged } \\
\text { between zero and } \\
(23.04) \text {, the fraction } \\
\text { consider as paraffinic } \\
\text { with lower naphthenic } \\
\text { content }\end{array}$ \\
\hline Gas Oil & $\begin{array}{c}\text { Heaviest } \\
\text { atmospheric } \\
\text { distillation } \\
\text { fraction, has low } \\
\text { API }\end{array}$ & $\begin{array}{l}\text { The temperature } \\
\text { decreases as aromatic } \\
\% \text { increases. so, this } \\
\text { fraction consider as it } \\
\text { is naphthenic or } \\
\text { aromatic rather than it } \\
\text { is paraffinic }\end{array}$ & $\begin{array}{l}\text { The value decreases } \\
\text { to (10.68) so, the } \\
\text { fraction consider as } \\
\text { low naphthenic to } \\
\text { high aromatic and } \\
\text { very low paraffinic } \\
\text { compounds }\end{array}$ & $\begin{array}{l}\text { The value increases } \\
\text { from (23.04) to } \\
\text { (31.79). so, paraffinic } \\
\text { compounds highly } \\
\text { decreases in this } \\
\text { fraction with } \\
\text { increasing naphthens } \\
\text { and aromatics }\end{array}$ \\
\hline
\end{tabular}

All the specifications in the tables and their scientific analyses confirm the findings in the section (3.1.1), although the description of the oil derivatives represents about half of the amount of crude oil at distillation as indicated in the Tables (5 and 6), which indicate that the product ratio is $50 \%$. 


\subsubsection{Fourier Transform Infrared Analysis}

Gas chromatography (GC), gas chromatography/mass spectroscopy (GCMS), liquid chromatography (LC) and thin layer chromatography (TLC), however, these technologies need time to run, sample preparation and have high cost. Easy and cheap technologies are needed which can be operated on the work site [18]. FT-IR spectroscopy is one of important the ancient that well determined experimental techniques [19].

Spectral techniques like infrared spectroscopy ultraviolet, mass spectrometry, nuclear magnetic resonance spectroscopy and emission spectroscopy were used extensively in crude oil analysis [20]. It is possible to say infrared technique can give qualitative information rather than quantitative [21]. Bruker FT-IR Spectrophotometer module (Alpha) was used to analyze crude oil fractions which were obtained from the selected crude oil samples by atmospheric distillation. Figures (2 and 3) illustrate FTIR spectrum for crude oil atmospheric distillation products for crude oil A and B respectively. Paraffins in Fig.(2), $\mathrm{CH}_{3}$ groups have $\mathrm{C}$-H stretching bands at 2956 and $2872 \mathrm{~cm}^{-1}$, while $\mathrm{CH}_{2}$ groups have frequency at 2922. Other characteristic bands for paraffins are the asymmetric scissoring bending vibrations for $\mathrm{CH}_{3}$ at $1374 \mathrm{~cm}^{-1}$ and a symmetric one at or near $1459 \mathrm{~cm}^{-1}$. Paraffins that have seven carbon atoms or more also exhibit a rocking vibrational band at $730 \mathrm{~cm}^{-1}$. Olefins give weak $\mathrm{C}-\mathrm{H}$ stretching bands above $3000 \mathrm{~cm}^{-1}$. Aromatic C-H stretching bands occur at the $3021 \mathrm{~cm}^{-1}$, while in-plane and outof-plane bending bands appear in 1300-1000 and $900-675 \mathrm{~cm}^{-1}$ sectors respectively. For aromatic compounds the later bands are the most informative bands. Based on the same findings in Fig.(4) for crude oil A, Fig.(3) refers to the same ingredients for crude oil $\mathrm{B}$ for the paraffinic and naphthenic components as in crude oil A but the main difference here is the disappearance of the bands for aromatics $\mathrm{C}-\mathrm{H}$ stretching occur above $3000 \mathrm{~cm}^{-1}$ for crude oil B [22]. we can conclude that crude oil A contain more aromatic compounds than crude oil B which confirms the same conclusions in the physical tests for crude oil samples and their atmospheric distillation products.

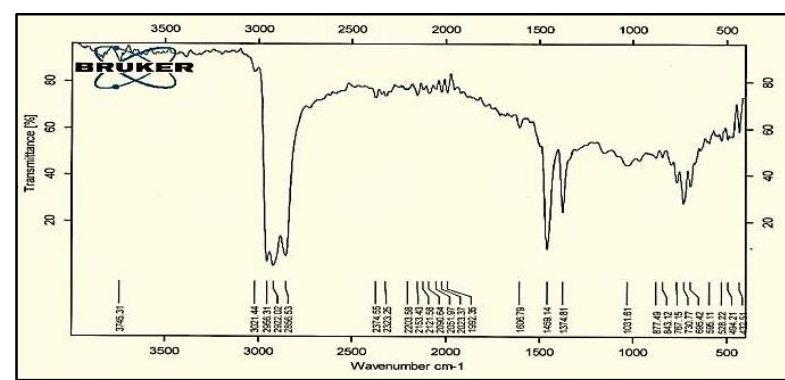

Fig.(2): FTIR spectrum for crude oil atmospheric distillation products for crude oil

A.

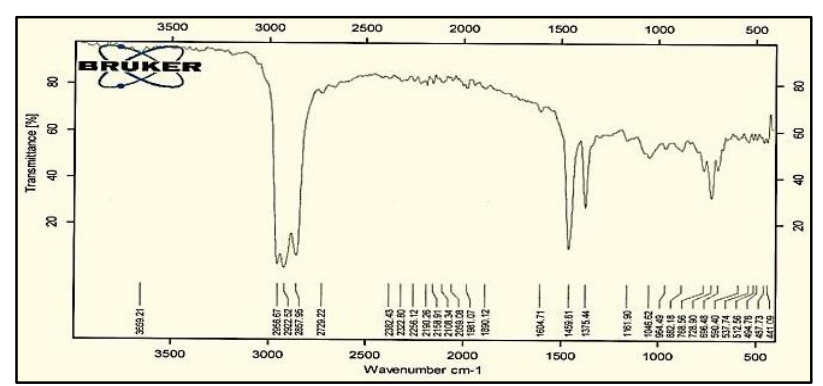

Fig.(3): FTIR spectrum for crude oil atmospheric distillation products for crude oil B.

\subsubsection{Ultraviolet Analysis for Crude Oil Fractions}

Routine tests of oil fractions need quick and cheap analysis methods considering that mass spectrometry is, however, used only for research applications [23]. Ultraviolet spectroscopy is a low cost technique used for monitoring some properties of petroleum products such as the aromatics content in some petroleum fractions [24]. These types of applications based on the strong absorption of ultraviolet radiation by aromatic compounds due to the occurrence of conjugated electrons their structure [25]. It should be mentioned that in the literature there are very few applications of ultraviolet spectroscopy of petroleum fractions. The ultraviolet spectra were obtained in a Hewlett Packard 8453 instrument. The solvent used was spectroscopic grade normal hexane. The thickness of the cells used was $1 \mathrm{~mm}$.

It is clear that both types of crude oil atmospheric distillation products $\mathrm{A}$ and $\mathrm{B}$ contains aromatic compounds illustrates in the region (230-270) $\mathrm{nm}$, but type A contains more of these aromatic hydrocarbons. This 
confirms the previous results in the physical analysis and FTIR Analysis.

\section{Conclusion}

The hydrocarbons present in crude petroleum are classified into three general types: paraffinic, naphthenic and aromatics. Although two samples of crude oil and its fractions were analyzed in this research, but the indication of being considering the type of crude oil as paraffinic or aromatic was clearly defined. Crude oil (A) shows it has more aromatic compounds than the crude oil (B) according to its higher $(\mathrm{Kw})$ and lower $(\mathrm{CI})$ values or (B) contain more paraffinic compounds than (A) for the same reasons. Fourier transform infrared and ultraviolet analysis were carried out to determine the main components in crude oil fractions for the selected crudes .Results obtains confirms the previous results in the physical analysis.

\section{Acknowledgements}

The authors acknowledge Al-Nahrain University, College of Science, Department of Chemistry for their encouragement and for the provision of facilities in chemical analysis.

\section{References}

[1] James G., Speight, The Chemistry and Technology of Petroleum, Marcel Dekker, 215-216, 1999.

[2] Odebunmi O., Adeniyi A., Infrared and Ultraviolet Spectrophotometric Analysis of Chromatographic Fractions of Crude Oils and Petroleum Products, Bull. Chem. Soc. Ethiop, 21(1), 135-140, 2007.

[3] Norman J., Nontechnical Guide to Petroleum Geology, Exploration, Drilling, and Production, (2nd Edition), Penn Well Corporation, Tulsa, Oklahoma, USA, 1-4, 2001.

[4] Oliver M., Eric S., Structure \& Dynamics of Asphaltenes, 1st Edition, Springer, (Chapter 1, page 17), 1999.

[5] Ante J., Petroleum Refining and Petrochemical Processes, Faculty of Chemical Engineering and Technology, University of Zagreb, 2009.

[6] Njeri H., "Industrial Chemistry", African Virtual University, 2007.
[7] Al-Dahhan W., Evaluation and Comparison between Crude Oil Straight Run Fractions and Its Commercial Fractions (Gasoline, Kerosene and Gas Oil) at Dura Oil Refinery, Journal of Al-Nahrain University,19 (3), 18-27, 2016.

[8] Chang A.F., "Refinery Engineering" Integrated Process Modeling and Optimization" First Edition, Amazon, 2012.

[9] Riazi M., Characterization and Properties of Petroleum Fractions, First Edition, ASTM, United State, 2005.

[10] James G., "The Chemistry and Technology of Petroleum" Fourth Edition, CRC Press, 2006.

[11] Glean E., James H., "Petrochemical Refining Technology and Economics" Fifth Edition, CRC Press, 2012.

[12] Albahri A., Octane Number and Aniline Point of Petroleum Fuels, Fuel Chemistry Division Preprints, 47(2), 710-711, 2002.

[13]Matar S., Chemistry of Petrochemical Processes, 2nd Edition, Elsevier, 2000.

[14] Mall I. D., Petrochemical Process Technology, New Delhi, Macmillan India 2007.

[15] Leffler W., "Petroleum Refining in Nontechnical Language", $4^{\text {th }}$ Edition, Oklahoma, 2000.

[16] Standard Test Method for Distillation of Crude Petroleum, ASTM Test Method D2892. West Conshocken (PA): ASTM, 2003.

[17] Al-Dahhan W., Evaluation and Comparison of the Quality of Two Crude Oils at Dura Oil Refinery, Journal of AlNahrain University 19 (1), 76-85, 2016.

[18] Abdulkadir I., Uba S., Salihu A., Almustapha M., A Rapid Method of Crude Oil Analysis Using FT-IR Spectroscopy, Nigerian Journal of Basic and Applied Science, 24(1),47-55, 2016.

[19] Akram E., Photochemical Study of Hydrated Ammonium Aluminum SulfateUrea Ionic Liquid by FT-IR Spectroscopy, Journal of Al-Nahrain University , 21(1), 41-45, 2018.

[20] James G., Handbook of Petroleum Product Analysis, John Wiley \& Sons, Inc., 2002.

[21] Sandra L., Artur M., Jorge C., Fernando G., Francisco A., Chromatographic and 
Spectroscopic Analysis of Heavy Crude Oil Mixtures with Emphasis in Nuclear Magnetic Resonance Spectroscopy: A review, Analytica Chimica Acta, Elsevier, 707, 18-37, 2011.

[22] Asfaha L., Mohammed A., Bassam S., Tawabini and Nureddin M., Hydrocarbon Group (PONA) Analysis of Reformate by FT-IR Spectroscopy, Fuel 75(9), 10601064, 1996.

[23] Carlos A., Luz Ángela N., Detailed Chemical Characterization of Petroleum Middle Fractions by Chemometrics Analysis of their Ultraviolet Spectrum, CT\&F - Ciencia, Tecnologíay Futuro, 3(3), 2007.

[24] Varotsis N., Pasadakis N., Rapid Determination of Aromatic Groups in Lubricating Oils using Gel Permeation Chromatography. Ind. And Eng. Chem. Res., 36 (12), 5516-5519, 1997.

[25] Scheinmann F., An Introduction to Spectroscopic Methods for the Identification of Organic Compounds, Oxford. Pergamon Press., 2, 110-111, 1973. 